\title{
Perbandingan Pola Pembinaan Prestasi Cabang Olahraga Bola Voli antara Kontingen Kabupaten Cianjur Dengan Kota Sukabumi
}

\author{
Doddy Dwy Payana ${ }^{1}$, Adi Rahadian², Andi Kurniawan Pratama ${ }^{3}$, Muhamad Syamsul Taufik ${ }^{4}$, Ari \\ Septian $^{5}$ \\ ${ }^{1,2,3,4}$ Pendidikan Jasmani Kesehatan dan Rekreasi, Fakultas Keguruan dan Ilmu Pendidikan, Universitas \\ Suryakancana, JL.Pasir Gede Bojong Herang Kec. Cianjur, Jawa Barat, Indonesia \\ ${ }^{5}$ Pendidikan Matematika,Fakultas Keguruan dan Ilmu Pendidikan, Universitas Suryakancana, JL.Pasir Gede \\ Bojong Herang Kec. Cianjur, Jawa Barat, Indonesia \\ *Corresponding Author. Email: Doddydwipayana@gmail.com ${ }^{1}$ adira@unsur.ac.id ${ }^{2}$ andikpratama@unsur.ac.id ${ }^{3}$ \\ syamsul@unsur.ac.id ${ }^{4}$ ariseptian@unsur.ac.id ${ }^{5}$
}

\begin{abstract}
Abstrak
Penelitian ini bertujuan untuk mengetahui: (1) untuk mengetahui pola pembinaan prestasi cabang olaharaga bola voli di Kabupaten Cianjur, (2) Untuk mengetahui pola pembinaan prestasi cabang olahraga bola voli Kota Sukabumi, (3) untuk mengetahui perbandingan pola pembinaan prestasi cabang olahraga bola voli antara Kabupaten Cianjur dengan Kota Sukabumi. Metode penelitian yang di gunakan adalah penelitian evaluasi yang menggunakan metode campuran kuantitatif dan kualitatif. Sasaran dalam peneltian ini adalah 30 atlet, 3 orang pelatih, 2 orang pengurus, dan 1 manager kontingen bola voli Kabupaten Cianjur dan Kontingen bola voli Kota Sukabumi melalui wawancara, angket, dokumentasi. Teknik analisis data menggunakan teknik analisis data deskrptif sedangkan perhitungan dalam angket menggunakan Microsoft Excel. Berdasarkan hasil penelitian ini menunjukan bahwa kualitas pola pembinaan kontingen bola voli Kabupaten Cianjur kurang baik dibandingkan kota Sukabumi bisa dilihat dari pola pembinaan, sarana prasarana dan prestasi. Kesimpulan dari penelitian ini adalah terdapat perbandingan yang signifikan pada kualitas pola pembinaan, sarana prasarana dan prestasi antara kontingen Kabupaten Cianjur dengan Kota Sukabumi.
\end{abstract}

Kata kunci: Olahraga Bola Voli, Pola Pembinaan, Prestasi

Comparison of the Patterns of Development of Achievement in Volleyball in the Branch of Cianjur District and Sukabumi City

\section{Abstract}

This study aims to find out: (1) to find out the pattern of performance training for volleyball sports branches in Cianjur Regency, (2) To find out the pattern of performance achievement for volleyball sports, Sukabumi City, (3) to find out the comparison of performance pattern training for volleyball sports between Cianjur Regency and Sukabumi City. The research method used is an evaluation research that uses a mixture of quantitative and qualitative methods. The targets in this research are 30 athletes, 3 trainers, 2 administrators, and 1 volleyball contingent manager in Cianjur Regency and the Sukabumi City volleyball contingent through interviews, questionnaires, documentation. Data analysis techniques using descriptive data analysis techniques while the calculation in a questionnaire using Microsoft Excel. Based on the results of this study indicate that the quality of the volleyball contingent coaching pattern is less good than the city of Sukabumi can be seen from the pattern of coaching, infrastructure and achievements. The conclusion of this study is that there is a significant comparison of the quality of the coaching pattern, infrastructure and achievements between the contingents of Cianjur Regency and Sukabumi City.

Keywords: volleyball, coaching pattern, performance 


\section{PENDAHULUAN}

Olahraga merupakan suatu bentuk aktifitas fisik yang terencana dan terstruktur dimana melibatkan gerakan tubuh berulang-ulang dan ditujukan untuk meningkatkan kebugaran jasmani manusia. Menurut (Rahadian, 2018) Olahraga juga merupakan salah satu media untuk membuat kondisi kesehatan manusia menjadi lebih baik dan terjaga. Bagi sebagian orang, olahraga tidak hanya sebagai gerakan untuk mengolah kebugaran jasmani, olahraga dapat dijadikan sebagai hobi yang dapat menunjang prestasi dan profesi seseorang. Untuk meningkatkan potensi yang dimiliki oleh atlet bola voli agar mendapatkan bimbingan dan pembinaan untuk memperoleh sebuah prestasi optimal sehingga nantinya akan meningkatkan harkat dan martabat bangsa(Rahadian \& Ma'mun, 2018).

Pada dekade terakhir ini perkembangan pola pembinaan dan pengembangan olahraga unggulan (Rahadian, Ma'mun, Berliana, \& Nuryadi, 2021a) meningkat, bola voli salah satunya. Menurut (Kao, Hsieh, \& Lee, 2017) "Coaching competency has grown in stature as a research topic and has gained increasing interest in the field of sports coaching over the last decad". Pembinaan merupakan suatu tempat latihan yang di bina oleh pelatih dan di dukung melalui pendanaan, perencanaan dan pengawasan. Menurut (Melfa Br Nababan, Rahma Dewi, 2018) pembinaan adalah suatu usaha dan kegiatan yang dilakukan demi mencapai perubahan dengan usaha yang keras demi hasil yang lebih baik melalui kegiatan perencanaan, pengorganisasian, pembiayaan, koordinasi, pelaksanaan dan pengawasan serta evaluasi yang digunakan sebagai mengukur keberhasilan proses pembinaan (Rahadian \& Ma'mun, 2018). Peran pelatih yang baik dalam pola pembinaan prestasi bola voli dapat meningkatkan kualitas atlet, menurut (Bolter, Petranek, \& Dorsch, 2018) Coaches play a significant role in determining the quality of these experiences, and coach-education and coachcertification programs have been designed to "prepare coaches for their important role in sport settings"'. Keefektifan seorang pelatih sangat penting dalam pola pembinaan (Rahadian, Ma'mun, Berliana, \& Nuryadi, 2021b). Menurut (Teatro, Thompson, Kulinna, Van Der Mars, \& Kwan, 2017) $a$ coach's efficacy is important in order to better understand an athlete's psyche and can lead to significantly improved sport performances.

Pembinaan serta pengembangan olahraga sebagai bagian dari usaha peningkatan kesehatan jasmani dan rohani seluruh masyarakat guna pembentukan watak, disiplin, sportifitas dan pengembangan. pembinaan yang baik dapat menghasilkan prestasi (Rahadian, Ma'mun, Berliana, \& Nuryadi, 2021c). Menurut (Mira Fauzita, 2017) Prestasi merupakan kombinasi kondisi fisik, kemampuan mental, penguasaan teknik, kecakapan teknik, yang diantaranya melalui pembinaan hingga mencapai prestasi puncak. Untuk mencapai prestasi atlet harus mempunyai kondisi fisilk yang baik. Kondisi fisik seorang atlet sangat penting dalam permainan bola voli. Menurut (Ever sovensi, Muhammad supriadi, 2019) komponen-komponen kondisi fisik seperti kekuatan otot perut, daya tahan, daya ledak otot tungkai, kecepatan dan kelincahan merupakan elemen yang sangat menunjang prestasi dalam cabang olahraga bolavoli. Dalam peningkatan prestasi olahraga untuk menuju pencapaian sasaran yang diharapkan dalam pembinaan olahraga diperlukan proses dan waktu yang lama. Menurut (Khoirul Anwar Pulungan \& Dimyati, 2019) olahraga prestasi menekankan pencapaian sebuah keberhasilan untuk menang pada sebuah pertandingan atau perlombaan yang nantinya ditekankan pada pencapaian prestasi puncak oleh seseorang atau kelompok pada cabang olahraga tertentu. Menurut (Sugiyanto, 2018) Pencapaian prestasi puncak dalam olahraga hanya dapat dicapai melalui proses pembinaan yang sistematik, terencana, teratur dan berkesinambungan. Menurut (Rumini \& Rani, 2016) Proses pembinaan yang baik akan berhasil bila faktor-faktor yang dilaksanakan dan tersedia dengan baik dalam proses pencapaian prestasi (Rahadian, Ma'mun, Berliana, \& Nuryadi, 2021b). Pendanaan juga sangat penting berlangsungnya pola pembinaan prestasi. Menurut (Ratna, Tangkudung, \& Hanif, 2018) Pendanaan menjadi salah satu faktor penting dalam pembinaan keolahragaan nasional (Rahadian, Ma'mun, Berliana, \& Nuryadi, 2021c). Meskipun dana bukan segalagalanya, tetapi tanpa adanya pendanaan yang cukup, sulit rasanya mengharapkan prestasi olahraga nasional tumbuh dan berkembang sesuai dengan yang diharapkan. 
Olahraga bola voli merupakan salah satu olahraga masyarakat yang populer di Indonesia (Rahadian, Ma'mun, Berliana, Nuryadi, et al., 2021), selain sepak bola. Menurut (Sarwita, 2018) Permainan bola voli dimainkan oleh dua regu yang saling berlawanan, dengan 6 orang pemain setiap regunya. Selain itu olahraga bola voli dapat dimainkan oleh berbagai usia dari anak-anak sampai dewasa. (Primayanti, 2016) Dalam permainan bolavoli, kekuatan otot lengan juga sangat diperlukan, karena tanpa adanya kekuatan otot lengan yang baik maka tidak akan dapat bermain bolavoli dengan dominan. Saat ini bola voli tidak hanya sebagai rekreasi, namun sudah menjadi bagian dari pendidikan. (Yuliawan, 2016) pendidikan merupakan salah satu faktor yang sangat penting dalam kehidupan seseorang karena melalui pendidikan seseorang dapat meningkatkan kecerdasan, keterampilan, mengembangkan potensi diri dan dapat membentuk pribadi yang bertanggung jawab, cerdas dan kreatif.. (Nasution, 2015)Permainan bola voli juga dapat dijadikan sebagai alat pendidikan dan olahraga yang merupakan salah satu sarana pembentukan karakter bangsa yang tangguh, sportif, berkpribadian luhur serta dapat menjadi atlet profesional yang memiliki prestasi gemilang

Pada penelitian ini penulis akan membandingkan pola pembinaan prestasi cabang olahraga bola voli antara kontingen kabupaten Cianjur dengan kota Sukabumi, di ajang PORDA Jawa Barat kontingen kabupaten Cianjur dengan kota Sukabumi, belum mempunyai prestasi yang membanggakan. Berdasarkan observasi yang dilakukan oleh Penulis bahwa Kontingen bola voli Kabupaten Cianjur dan Kota Sukabumi sedang menurun, minat atlet bermain bola voli menurun dan bola voli kurang bermasyarakat serta masyarakat lebih tertarik olahraga sepak bola dibandingkan bola voli. Peneliti memilih judul penelitian tersebut karena ada beberapa alasan yaitu: 1) Prestasi tim bola voli putra putri Kabupaten Cianjur dan Kota Sukabumi belum ada yang membanggakan di tingkat PORDA. 2) Belum diketahui tingkat keterampilan dasar bermain bola voli atlet putra dan putri Kabupaten Cianjur dan Kota Sukabumi. 3) Belum diketahui pola pembinaan prestasi cabang olahraga bola voli Kabupaten Cianjur dan Kota Sukabumi. Berdasarkan uraian di atas penulis tertarik untuk melakukan penelitian mengenai "Perbandingan Pola Pembinaan Prestasi Cabang Olahraga Bola Voli antara Kontingen Kabupaten Cianjur dengan Kota Sukabumi.

\section{METODE}

Menurut (Irmansyah, Mataram, Pemuda, Mataram, \& Irmansyah, 2017) Penelitian ini adalah penelitian evaluasi yang menggunakan metode campuran kuantitatif dan kualitatif. Dari paparan diatas bahwa dalam penelitian ini penulis mencoba mencari perbandingan yang ditimbulkan oleh variable bebas yaitu pola pembinaan kontingen bola voli kabupaten Cianjur (X1), Pola pembinaan kontingen kota Sukabumi (X2) terhadap variabel terikat yaitu prestasi cabang olahraga bola voli (Y). Lokasi penelitian secara online di dua tempat yaitu KONI Kabupaten Cianjur Jl. Slamet Riyadi, Pamoyanan, Kecamatan Cianjur, Kabupaten Cianjur, dan KONI Kota Sukabumi, JL. Rh. Didi Sukardi No.37, Gedongpanjang Kecamatan Citamiang, Kota Sukabumi. Waktu penelitian secara online pada tanggal 11 s.d 18 Mei 2020. Menurut (Komarudin, 2016) populasi adalah seluruh karakteristik yang ada dalam suatu kelompok yang menjadi objek penelitian. Terkait dalam penjelasan tersebut maka populasi dalam penelitian ini adalah 30 orang atlet Kabupaten Cianjur dan 30 orang atlet Kota Sukabumi. Menurut (Taufik et al., 2020) analisis data dilakukan secara deskriptif dengan membandingkan hasil pencapaian dengan indikator keberhasilan. Sample penelitian sebanyak 15 orang atlet laki-laki Kabupaten Cianjur, 15 orang atlet perempuan Kabupaten Cianjur dan 15 orang laki-laki Kota Sukabumi, 15 orang atlet perempuan Kota Sukabumi. Menurut (Rudiansyah, Soekardi, \& Hidayat, 2017) pengumpulan data adalah pencatatan peristiwa, hal-hal, keterangam-keterangan dan karateristik atau seluruh elemen yang akan menunjang dan mendukung penelitian. Pengumpulan data dilakukan dengan menggunakan teknik-teknik tertentu, berdasarkan caranya dikenal berbagai pengumpulan data yaitu, wawancara, angket, dokumentasi, dan observasi. Teknik analisis data pola pembinaan prestasi cabang olahraga bola voli antara Kabupaten Cianjur dengan Kota Sukabumi melalui aplikasi Microsoft Excel.

\section{HASIL DAN PEMBAHASAN}


JORPRES (Jurnal Olahraga Prestasi), 17 (01), 2021 - 4

Doddy Dwy Payana, Adi Rahadian, Andi Kurniawan Pratama, Muhamad Syamsul Taufik, Ari Septian

Instrumen yang digunakan untuk mengukur pola pembinaan prestasi menggunakan

\begin{tabular}{|l|c|c|c|c|c|c|}
\hline No & $\begin{array}{l}\text { Atlet } \\
\text { Cianjur }\end{array}$ & $\begin{array}{l}\text { Atlet } \\
\text { Sukabumi }\end{array}$ & $\begin{array}{l}\text { Pelatih } \\
\text { Cianjur }\end{array}$ & $\begin{array}{l}\text { Pelatih } \\
\text { Sukabumi }\end{array}$ & $\begin{array}{l}\text { Pengurus } \\
\text { Cianjur }\end{array}$ & $\begin{array}{l}\text { Pengurus } \\
\text { Sukabumi }\end{array}$ \\
\hline $\mathrm{N}$ & 30 & 30 & 3 & 3 & 2 & 2 \\
\hline Ya & $90 \%$ & $90 \%$ & $80 \%$ & $85 \%$ & $71 \%$ & $81 \%$ \\
\hline Tidak & $10 \%$ & $10 \%$ & $20 \%$ & $15 \%$ & $29 \%$ & $19 \%$ \\
\hline
\end{tabular}

wawancara, dokumentasi dan kuesioner. Prosedur penelitian sebanyak 30 orang atlet Kabupaten Cianjur dan 30 orang atlet Kota Sukabumi, 3 orang pelatih dan 2 orang pengurus. Terjun ke lapangan secara online untuk melakukan penelitian dan pengambilan data, mengolah data penelitian menggunakan menggunakan microsoft excel. Teknik analisis data yang di gunakan jumlah persen ya, jumlah persen tidak, rata-rata prsentase.

Tabel 1 data Atlet Presentase Atlet pelatih Kota sukabumi dan Kabupaten Cianjur

Berdasarkan hasil data di atas, dapat diketahui bahwa 30 orang atlet Kabupaten Cianjur dan 30 orang atlet kota Sukabumi yang menjawab responden ya sebanyak 37 pertanyaan adalah $90 \%$ sedangkan yang menjawab responden tidak sebanyak 10\%. 3 orang Pelatih Kabupaten Cianjur yang menjawab responden ya sebanyak 32 pertanyaan adalah $80 \%$ sedangkan yang menjawab responden tidak sebanyak 20\% sedangkan untuk pelatih kota Sukabumi yang menjawab responden ya $85 \%$ yang menjawab responden tidak 15\%. 2 orang pengurus Kabupaten Cianjur yang menjawab responden ya sebanyak 26 pertanyaan adalah $71 \%$, yang menjawab responden tidak sebanyak $29 \%$ sedangkan pengurus kota Sukabumi responden ya sebanyak 26 pertanyaan adalah $85 \%$ yang menjawab responden tidak sebanyak $15 \%$. Hasil tesebut bisa di lihat dari grafik di atas, bahwa perbandingan pola pembinaan kontingen bola voli Kabupaten Cianjur dan Pola pembinaan kontingen Kota Sukabumi dapat di ketahui kontingen atlet Kabupaten Cianjur masih kurang dari kontingen Kota Sukabumi.

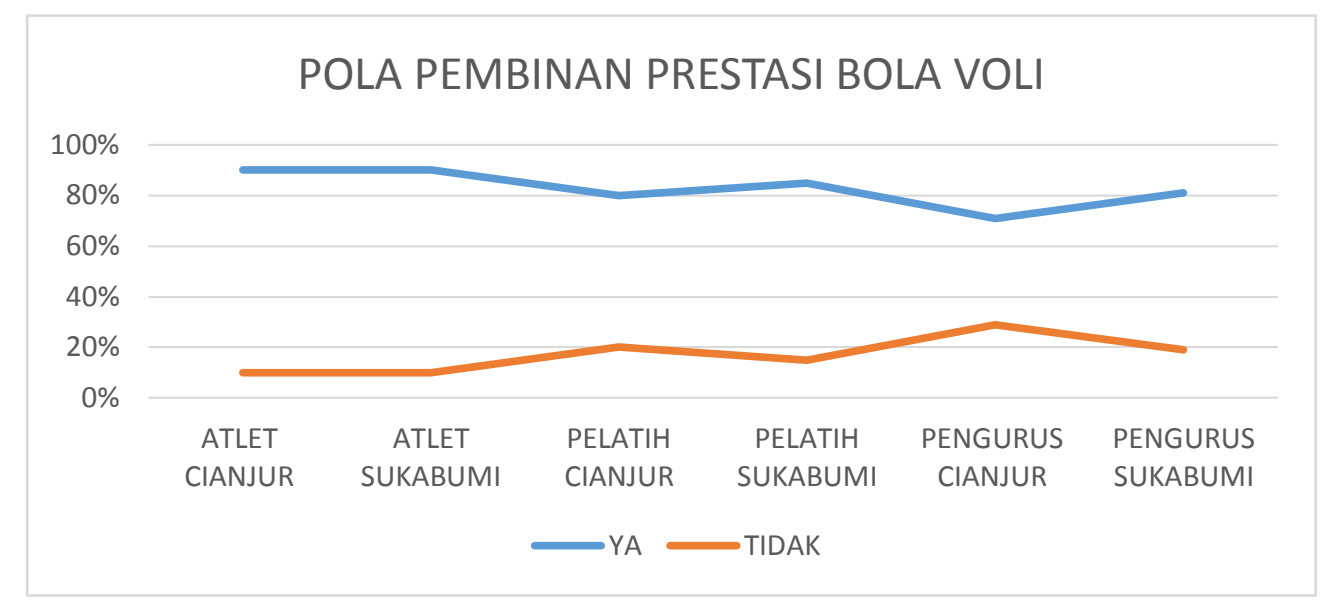

Gambar 1 Grafik Pola Pembinan Prestasi Bola Voli

\section{Pembahasan}


Efektifitas pembinaan olahraga perlu dilakukan secara terus menerus, berjenjang, berkelanjutan dan berkesinambungan melalui proses panjang untuk dapat diperoleh atlet yang handal. Menurut (Kramers, Turgeon, Bean, Sabourin, \& Camiré, 2020) coaching effectiveness as "the consistent application of integrated professional, interpersonal, and intrapersonal knowledge to improve athletes' competence, confidence, connection, and character in specific coaching contexts". Pembinaan olahraga yang optimal dapat dicapai dengan pembinaan yang baik dan benar sebagai satu keutuhan. Menurut (Sidu Trimukti Hariandes, 2016) pembinaan olahraga merupakan faktor yang sangat penting dalam memajukan serta meningkatkan prestasi olahraga, karena berkembang tidaknya dunia olahraga itu tergantung pada pembinaan olahraga itu sendiri, baik pembinaan di lingkungan masyarakat, sekolah, maupun di tingkat daerah, nasional, bahkan internasional. Sistem pembinaan prestasi yang terencana dapat meningakatkan kualitas atlet untuk mencapai prestasi. Menurut (Suparno, Hidayanto, \& Labulan, 2019) sistem pembinaan prestasi olahraga di Indonesia adalah pemanduan bakat dan pengembangan bakat. Peran pembinaan prestasi harus diprogramkan secara optimal, untuk mengorganisasi jalannya pembinaan sesuai dengan program yang telah disusun dalam sistem pembinaan prestasi atlet. Menurut (Hamzah, 2017) untuk mencapai prestasi yang baik beberapa faktor yang dapat dikembangkan melalui peningkatan penguasaan terhadap unsur-unsur yang diperlukan, yang meliputi kondisi fisik, teknik, taktik dan mental. Bola voli merupakan salah satu cabang olahraga yang populer dikalangan masyarakat Indonesia dari kalangan bawah hingga atas olahraga. Menurut (Hary, 2019) bola voli merupakan suatu permainan yang kompleks yang tidak mudah dilakukan oleh setiap orang, sebab dalam permainan bolavoli dibutuhkan koordinasi gerak yang benar-benar bisa diandalkan untuk melakukan semua gerakan yang ada dalam permainan bola voli. Dalam pembinaan peran pelatih sangat penting dalam kefektifan program latihan, menurut (Teatro et al., 2017) a coach's efficacy is important in order to better understand an athlete's psyche and can lead to significantly improved sport performances.

Hasil temuan dalam penelitian ini menunjukkan bahwa terdapat perbandingan pola pembinaan prestasi cabang olahraga bola voli Kabupaten Cianjur dengan Kota Sukabumi. Untuk Kabupaten Cianjur pola Pembinaan kontingen bola voli Kabupaten Cianjur diarahkan pada proses latihan yang sesuai dengan kebutuhan peningkatan prestasi atlet. Dalam hal ini, peran pelatih sangat penting dalam menentukan keberhasilan atlet. Sebagai pelatih kontingen bola voli Kabupaten Cianjur, pelatih berusaha semaksimal mungkin dalam membina atlet. Dalam proses pembinaan, beliau mengevaluasi secara berkala yang ditujukan pada peningkatan prestasi atlet secara periodik dan segera melakukan perbaikan apabila dibutuhkan. Sedangkan untuk Kota Sukabumi Program latihan, latihan, lembaga yang bertanggung jawab, sarana dan prasarana, dan pendanaan berada pada kondisi yang ideal untuk mencapai tujuan pembinaan prestasi yang diharapkan. Sedangkan kegiatan pembinaan dikatakan kurang baik apabila komponen-komponen pembinaan berada pada kondisi sangat terbatas atau kurang ideal sehingga pencapaian tujuan pembinaan prestasi tidak dapat tercapai secara maksimal. Pola pembinaan prestasi di Kontingen Bola Voli Kota Sukabumi ini telah memenuhi kriteria dan komponen dalam pembinaan prestasi tersebut. Talent scouting maksudnya proses pemanduan bakat atlet dari mulai tahap perekrutan sampai tahap akhir pelaksanaan pembinaan. Sesuai dengan sistem piramida pembinaan prestasi olahraga yaitu melalui pembibitan, pemanduan bakat, dan pematangan juara.

\section{SIMPULAN}

Berdasarkan hasil data dan pembahasan di atas bahwa pola pembinaan kontingen bola voli Kabupaten Cianjur diarahkan pada proses latihan yang sesuai dengan kebutuhan peningkatan prestasi atlet. Dalam hal ini, peran pelatih sangat penting dalam menentukan keberhasilan atlet. Sebagai pelatih kontingen bola voli Kabupaten Cianjur, pelatih berusaha semaksimal mungkin dalam membina atlet. Dalam proses pembinaan, beliau mengevaluasi secara berkala yang ditujukan pada peningkatan prestasi atlet secara periodik dan segera melakukan perbaikan apabila dibutuhkan. Sedangkan kontingen Kota Sukabumi Pembinaan diarahkan pada program latihan, lembaga yang bertanggung jawab, sarana dan prasarana, dan pendanaan berada pada kondisi yang ideal untuk mencapai tujuan pembinaan prestasi yang diharapkan. Pola pembinaan prestasi di kontingen bola voli Kota Sukabumi melalui Talent scouting maksudnya proses pemanduan bakat atlet dari mulai tahap perekrutan sampai 
JORPRES (Jurnal Olahraga Prestasi), 17 (01), 2021 - 6

Doddy Dwy Payana, Adi Rahadian, Andi Kurniawan Pratama, Muhamad Syamsul Taufik, Ari Septian

tahap akhir pelaksanaan pembinaan. Sesuai dengan sistem piramida pembinaan prestasi olahraga yaitu melalui pembibitan, pemanduan bakat, dan pematangan juara. Oleh karena itu, peneliti menarik kesimpulan bahwa terdapat perbandingan yang signifikan pada kualitas pola pembinaan, sarana prasarana dan prestasi antara kontingen Kabupaten Cianjur dengan Kota Sukabumi. Kualitas pola pembinaan kontingen bola voli Kabupaten Cianjur kurang baik dibandingkan kota Sukabumi bisa dilihat dari pola pembinaan, sarana prasarana dan prestasi. 


\section{DAFTAR PUSTAKA}

Bolter, N. D., Petranek, L. J., \& Dorsch, T. E. (2018). Coach, parent, and administrator perspectives on required coaching education in organized youth sport. International Journal of Sports Science and Coaching, 13(3), 362-372. https://doi.org/10.1177/1747954117735718

Ever sovensi, Muhammad supriadi, M. suhdy. (2019). Kondisi fisik pemain bola voli. Journal of Chemical Information and Modeling, 53(9), 1689-1699. https://doi.org/10.1017/CBO9781107415324.004

Hamzah. (2017). STUDI KONDISI FISIK PADA CLUB PUTRA BOLA VOLI SMP AL-AZHAR MANDIRI PALU HAMZAH. Sport Sciences and Physical Education Volume, VI(1), 66-79.

Hary, V. (2019). Pengembangan Model Passing Atas Bolavoli Untuk Usia Smp. Briliant: Jurnal Riset Dan Konseptual, 4(1), 63. https://doi.org/10.28926/briliant.v4i1.270

Irmansyah, J., Mataram, I., Pemuda, J., Mataram, N., \& Irmansyah, J. (2017). Evaluasi Program Pembinaan Prestasi Cabang Olahraga Bola Voli Pantai. Keolahragaan, 5(59), 24-38. https://doi.org/Prefix 10.21831

Kao, S. F., Hsieh, M. H., \& Lee, P. L. (2017). Coaching competency and trust in coach in sport teams. International Journal of Sports Science and Coaching, 12(3), 319-327. https://doi.org/10.1177/1747954117710508

Khoirul Anwar Pulungan, \& Dimyati. (2019). Karakteristik keterampilan psikologis pemain bolavoli Indonesia ditinjau berdasarkan gender dan posisi The psychological skill characteristics of Indonesian volleyball players reviewed based on gender and position PENDAHULUAN Olahraga prestasi dilaksanaka. Sportif: Jurnal Penelitian Pembelajaran, 5(2), 279-295.

Komarudin, H. S. (2016). PROFIL PEMBINAAN ATLET POTENSIAL KONI KOTA BANDUNG (Upaya Menjaring Data Calon Atlet Potensial untuk Persiapan Porda XIII di Kabupaten Bogor). Jurnal Kepelatihan Olahraga, 8(2), 11-24.

Kramers, S., Turgeon, S., Bean, C., Sabourin, C., \& Camiré, M. (2020). Examining the roles of coaching experience and coach training on coaches' perceived life skills teaching. International Journal of Sports Science and Coaching. https://doi.org/10.1177/1747954120922367

Melfa Br Nababan, Rahma Dewi, I. A. (2018). Analisis Pola Pembinaan Dan Pengembangan Olahraga Rekreasi Di Federasi Olahraga Rekreasi Masyarakat Indonesia Sumatera Utara Tahun 2017. Jurnal Pedagogik Olahraga, 4(1), 38-55.

Mira Fauzita, I. (2017). IKIP PGRI PONTIANAK. Jurnal Pendidikan Olahraga, 6(2), 119-128. https://doi.org/10.31571/jpo.v6i2.672

Nasution, N. S. (2015). Hubungan Kekuatan Otot Lengan Dan Percaya Diri Dengan Keterampilan Open Spike Pada Pembelajaran Permainan Bola Voli Atlet Pelatkab Bola Voli Putri Kabupaten Karawang. Jurnal Pendidikan Unsika], 3(2), 188-199.

Primayanti, I. (2016). Perbedaan Pengaruh Metode Latihan Plyometrik dan Berbeban terhadap Peningkatan Kecepatan Smash Bolavoli Ditinjau dari Kekuatan Otot Lengan. Jurnal Pendidikan Olahraga Dan Kesehatan “GELORA,” 3(ISSN: 2355-4355), 393-404.

Rahadian, A. (2018). Aplikasi Analisis Biomekanika Untuk Mengembangkan Kemampuan Lari Jarak Pendek (100 M) Mahasiswa Pjkr Unsur (Kinovea Software. Maenpo, 8(1), 2. https://doi.org/10.35194/jm.v8i1.912 
Rahadian, A., \& Ma'mun, A. (2018). Kebijakan Olahraga dalam Pemerintahan Lokal: Sebuah Penelitian dalam Merumuskan Rancangan Induk Pembangunan Olahraga Nasional. Prosiding Seminar Pendidikan Jasmani-FPOK UPI, (Sport Policy), 1-12. Retrieved from https://www.researchgate.net/publication/342260670

Rahadian, A., Ma'mun, A., Berliana, \& Nuryadi. (2021a). 2018 Asian Games Success : Policies for the Development of Indonesian Elite Athlete. Maenpo, 11(1), 1-12. https://doi.org/https://doi.org/10.35194/jm.v11i1.1278

Rahadian, A., Ma'mun, A., Berliana, \& Nuryadi. (2021b). SPORT POLICY INDONESIA : ELITE SPORT DEVELOPMENT. THE ASEAN JOURNAL OF SPORT FOR DEVELOPMENT \& PEACE, 1(1), 19-26. https://doi.org/P.ISSN 2807-1611 E.ISSN 280701638

Rahadian, A., Ma'mun, A., Berliana, \& Nuryadi. (2021c). Successful Elite Sport Policies: Indonesia at The 2018 Asian Games. Juara: Jurnal Olahraga, 6(2), 288-303. https://doi.org/https://doi.org/10.33222/juara.v6i2.1327

Rahadian, A., Ma'mun, A., Berliana, Nuryadi, Mutohir, T. C., \& Irianto, D. P. (2021). Gerakan Sport for All Kunci Keberhasilan Olahraga Indonesia, 1(1), 78-95. https://doi.org/2807-998

Ratna, D., Tangkudung, S. J., \& Hanif, A. S. (2018). Evaluasi Program Pemusatan Latihan Daerah (Pelatda) Bolavoli Pasir Putri Dki Jakarta. Jurnal Ilmiah Sport Coaching and Education, 2, 8-16.

Rudiansyah, E., Soekardi, \& Hidayat, T. (2017). Pembinaan olahraga prestasi unggulan di kabaputen melawi kalimatan barat. Jurnal Pendidikan Jasmani Kesehatan Dan Rekreasi (Penjaskesrek), 4, $1-14$.

Rumini, \& Rani, A. (2016). 10734-Article Text-21426-2-10-20180414. Journal of Physical Education, Sport, Health and Recreations, 5(2), 47-52.

Sarwita, T. (2018). SURVEI PENGUASAAN PUKULAN SMASH BOLA VOLI PADA CLUB IVOMAG V.C Tuti. Journal of Chemical Information and Modeling, 53(9), 1689-1699. https://doi.org/10.1017/CBO9781107415324.004

Sidu Trimukti Hariandes, A. S. (2016). Evaluasi Pembinaan Cabang Olahraga Bolavoli Surabaya EVALUASI. Jurnal Kesehatan Olahraga, 04(03), 1-12. https://doi.org/10.5151/cidi2017-060

Sugiyanto, B. R. I. (2018). EVALUASI PROGRAM PEMBINAAN PRESTASI OLAHRAGA BOLA VOLI PADA SMK NEGERI DI KOTA BENGKULU Yunita. Ilmiah Pendidikan Jasmani, 2(1), 44-48. https://doi.org/10.33369/jk

Suparno, Hidayanto, D. N., \& Labulan, P. (2019). Manajemen Pembinaan Prestasi Olahraga di Sekolah Khusus Olahragawan Internasional (SKOI) Kalimantan Timur. Jurnal Pendas Mahakam, 53(9), 1689-1699. https://doi.org/10.1017/CBO9781107415324.004

Taufik, M. S., Kosasih, A. H., Suryakancana, U., Tinggi, S., Ilmu, K., Cianjur, K., ... Alat, M. (2020). MENINGKATKAN KETERAMPILAN PASING ATAS BOLA VOLI MELALUI MODIFIKASI ALAT PADA SISWA KELAS X SMK 4 KOTA, 19(April), 83-92. https://doi.org/http://dx.doi.org/10.20527

Teatro, C., Thompson, M., Kulinna, P. H., Van Der Mars, H., \& Kwan, J. Y. (2017). Coaching behaviors and stakeholders' views of coaches' efficacy. International Journal of Sports Science and Coaching, 12(4), 452-460. https://doi.org/10.1177/1747954117718094

Yuliawan, D. (2016). Pembentukan Karakter Anak Dengan Jiwa Sportif Melalui Pendidikan Jasmani Olahraga dan Kesehatan. Jurnal SPORTIF: Jurnal Penelitian Pembelajaran, 2(1), 101. https://doi.org/10.29407/js_unpgri.v2i1.661 